\title{
VII. On the longitudes of the Trigonometrical Survey of England
}

\section{Dr. J.L. Tiarks F.R.S.}

To cite this article: Dr. J.L. Tiarks F.R.S. (1829) VII. On the longitudes of the Trigonometrical Survey of England, Philosophical Magazine Series 2, 5:25, 52-53, DOI: $10.1080 / 14786442908674912$

To link to this article: http://dx.doi.org/10.1080/14786442908674912

里 Published online: 10 Jul 2009.

Submit your article to this journal $[\pi$

Џll Article views: 1

Q View related articles $๘$ 
957,000 pounds. Upon examining the experiments of $\mathrm{Mr}$. Barlow and of Mr. Tredgold on ash timber, it will be found that the modulus of elasticity of the specimens tried by them was $1,645,187$ and $1,525,500$ pounds respectively; so that the flexibility of Earls-Barton ash, when compared with the wood tried by Mr. Barlow and Mr. Tredgold, is nearly as 5 to 3. The cohesion of Earls-Barton ash, as deduced from its transverse strength, I found to be little more than 10,000 pounds per square inch : but upon trying the cohesion by the direct longitudinal force to pull it asunder, I obtained 24,700 pounds.

Mr. Barlow gives the cohesion of ash 17,337 pounds, and Mr. Tredgold 14,130 pounds; the mean of these being 15,733 pounds: from which it appears that Earls-Barton ash is superior to those just referred to in the ratio of 11 to 7 .

The ultimate deflection before fracture took place, according to the formula of $\mathrm{Mr}$. Barlow, I found to be about $2 \frac{1}{2}$ times greater than the ultimate deflection of ash in Mr. Barlow's tables.

Now if we estimate the toughness of wood to be in the compound proportion of its cohesive strength and its ultimate deflection, we shall have $\frac{24,700}{2}: \frac{17,337}{5}:: 12,350: 3465$; or in small numbers, $7: 2$ nearly; which shows that where toughness is an essential quality, the ash growing in the neighbourhood of Earls Barton excells other wood of the same species, and tried by Mr. Barlow, in the scale of $3 \frac{1}{2}$ to 1 .

I am, Gentlemen, yours truly,

Leighton Buzzard, Dec. 12, 1828.

B. Bevan.

VII. On the Longitudes of the Trigonometrical Survey of England. By Dr. J. L. Tianks, F.R.S. \&c.*

MR. IVORY has proved (Phil. Mag. and Annals, July, page 10) that, according to our present knowledge of the figure of the earth, the difference of longitude between Beachy Head and Dunnose ought to be $18^{\prime \prime}$ more than the result reduced in the Trigonometrical Survey; and he has subsequently (Phil. Mag. and Annals, October, page 244) endeavoured to account for a part of this difference, by proving an error in the formula by which that difference of longitude was calculated from the data furnished by the Survey. The formula is this (retaining $\mathrm{Mr}$. Ivory's symbols):

$$
\text { Tang } \frac{1}{2} \omega=\frac{\cos \left(\frac{\lambda-\lambda^{\prime}}{2}\right)}{\sin \left(\frac{\lambda+\lambda^{\prime}}{2}\right)} \operatorname{cotang} \frac{m+m^{\prime}}{2}
$$

* Communicated by the Author. 
Now Mr. Ivory contends that the quantity on the right-hand ought to be multiplied by $\left(1+\frac{e^{2}}{2} \cos \left(\frac{\lambda+\lambda^{\prime}}{2}\right)^{2}\right)$; thus adding to the former value of tang $\frac{1}{2} \omega$ a quantity multiplied by the square of the excentricity, which increases the value of w deduced from the formula by a quantity nearly equal to $\frac{e^{2}}{2} \cos \left(\frac{\lambda+\lambda^{\prime}}{2}\right)^{2} \sin \omega$. In the case in question this quantity amounts to $7^{\prime \prime}$, and would thus leave only $11^{\prime \prime}$ of the difference in longitude to be accounted for by the errors in the data of the Survey, principally by the errors in the sum of the azimuths. I have endeavoured to prove that in the development of the value of tang $\frac{1}{2} \omega$ there is no such term, involving the square of the excentrictiy, and Mr. Ivory's last paper has not proved the contrary. At the same time I have fallen into the mistake of contending that the formula for tang $\frac{1}{2} \omega$ is rigorously correct; while it really contains terms proportional to the fourth and higher powers of the excentricity. The mistake has arisen from my confounding the azimuth of the station observed with the azimuth of the geodetical line connecting the stations at the place of observation. For the azimuth of the geodetical line at $\mathrm{B}$ we may take that of the point of intersection of the vertical line at $\mathrm{D}$ with the horizon of $\mathrm{B}$. Calling $\mathrm{B}$ and $\mathrm{D}$ the azimuths of the geodetical line at $\mathrm{B}$ and $\mathrm{D}$, it will be found that nearly $\mathrm{B}-m=m^{\prime}-\mathrm{D}=$

$$
e^{2} \cdot\left(\sin \lambda-\sin \lambda^{\prime}\right) \sin m \cdot \cos \lambda \cdot \operatorname{tang} \frac{1}{2} \beta,
$$

and $\mu+\mu^{\prime}=m+m^{\prime}-\frac{e^{4}}{2} \cdot\left(\sin \lambda-\sin \lambda^{\prime}\right)^{2} \cdot \frac{\sin \left(m+m^{\prime}\right) \cos \lambda \cdot \cos \lambda^{\prime}}{\cos \frac{\lambda}{2} \beta^{2} \cdot}$.

This value of $\mu+\mu^{\prime}$ ought to be substituted in the exact formula

$$
\text { Tang } \frac{1}{2} \omega=\frac{\cos \left(\frac{\lambda-\lambda}{2}\right) \cdot \operatorname{cotang}\left(\frac{\mu+\mu^{\prime}}{2}\right)}{\sin \left(\frac{\lambda+\lambda^{\prime}}{2}\right)}
$$

The three quantities $\mathrm{B}+\mathrm{D}, m+m^{\prime}$, and $\mu+\mu^{\prime}$, are consequently only equal as far as terms involving powers of the excentricity below the fourth are taken into account. As Mr. Ivory intends to deduce the value of $\omega$ expressed by the quantities $m, m^{\prime}, \lambda, \lambda^{\prime}, e$ from the equations $\mathrm{A}$ of his paper, he will, no doubt, decide whether Dalby's expression for tang $\frac{1}{2} \omega$ or the same with his correction is more accurate.

Dec. ]2, 1828.

J. L. Tiarks. 